\title{
THE THRESHOLD CURRENT REDUCTION IN InGaAsSb STRUCTURE WITH STRAIN LAYERS
}

\author{
O. V. Mashoshina, V. V. Lysak, I. A. Sukhoivanov \\ Kharkiv National University of Radioelectronics, \\ Lab. Photonics, Lenin av. 14, Kharkiv, 61166, Ukraine
}

(Received December 12, 2002)

\begin{abstract}
In this work the theoretical investigation of temperature dependence of the threshold current in quantum well structure of mid-IR range with strain layers based on InGaAsSb/AlGaAsSb structure has been made. As an example of processes which have an influence on the threshold current temperature dependence the Auger recombination have been chosen. This process exerts the largest influence on the temperature dependence. The obtained Auger recombination versus As mole fraction dependence illustrates the way of this lost mechanism reduction by fitting structure material and its mole fractions in such lasers. The presence of such a result allows to reduce nonradiative losses and the threshold current temperature dependence.
\end{abstract}

Ключові слова: mid-IR lasers, threshold current, Auger recombination.

PACS number(s): 42.55.Px, 79.20.Fv

High performance long wavel ength mid-IR lasers emitting at the wave length greater than or equal to $2 \mu \mathrm{m}$ are of great interest because their wavelengths coincide with the atmospheric transparence window. These lasers can be used in the following applications: environmental monitoring (in this spectral region the water vapour absorption is very weak while absorption lines of some pollutants are very strong). Other fields in which mid-IR lasers can work are remote sensing, molecular spectroscopy, solid-state lasers and mid-IR semiconductor lasers pumping, infrared countermeasurements, laser radar and communications. The main requirements for semiconductor lasers are performance above room temperature and high emitting efficiency.

The structures with strain layers allow to get low threshold current that is related semiconductor band structure modification. The strain presence permits to change such important material parameters as the lattice constant, the band gap energy as well as and the effective mass value.

Semiconductor lasers based on InGaAsSb/GaSb have low threshold current density, but their internal quantum efficiency is not greater than $47 \%$ and output continuous wave optical power at room temperature is only $2 \mathrm{~mW}$. However, these quantum structures with barrier layers AlGaAsSb and active layers InGaAsSb have high values of their internal quantum efficiency and the output continuous wave optical power at room temperature of $1.9 \mathrm{~W}$ [1]. It makes lasers diode based on such materials fetching as radiation sources for spectroscopic atmosphere investigation.

One of the main working characteristics of semiconductor lasers is the dependence of the threshold current versus temperature. The formula for the threshold current temperature dependence is defined as [2]:

$$
\begin{aligned}
& I_{\mathrm{th}}(T)=I_{0} \exp \left(T / T_{0}\right) \\
& =\frac{e N_{w} L_{z} N W}{\eta_{i}}\left(A n+B n^{2}+C n^{3}\right)+I_{\text {leakage }}
\end{aligned}
$$

where $I_{0}$ is the constant; $T_{0}$ is the characteristic temperature which is used for description threshold current temperature sensitivity; $e$ is the electron charge; $N_{w}$ is number of quantum wells; $L_{z}$ is the quantum well thickness; $N$ is the quantum well length; $W$ is the quantum well width; $\eta_{i}$ is the internal quantum efficiency; $A$ is the molecular recombination coefficient (defect and surface recombination); $n$ is the carrier density; $B$ is the bimolecular recombination coefficient; $C$ is the coefficient of nonradiative or Auger recombination; $I_{\text {leakage }}$ is the leakage current. Each component of the formula describes corresponding current terms:

$$
I_{\mathrm{th}}(T)=I_{A}+I_{B}+I_{C}+I_{\text {leakage }} .
$$

Strong temperature dependence of the threshold current limits the laser application range. The processes of non-radiative Auger recombination, intersubband absorption and leakage current exert negative influence on this characteristic. It has been found out that the Auger recombination plays a principal part [3] and leads to the increase of the threshold current and its temperature sensitivity (in this case the characteristic temperature $T_{0}$ decreases).

Processes of non-radiative recombination predominate at room temperature and lead to a sharp threshold current increase under the temperature rise. Thus, these processes are the main lost mechanism of long wavel ength lasers.

The goal of our work is the theoretical investigation of temperature dependence of threshold current $I_{\text {th }}$ in quantum well structure of mid-IR range with strain layers based on $\operatorname{In}_{(1-x)} \mathrm{Ga}_{x} \mathrm{As}_{y} \mathrm{Sb}_{(1-y)} / \mathrm{Al}_{(1-x)} \mathrm{Ga}_{x} \mathrm{As}_{y} \mathrm{Sb}_{(1-y)}$.

One of the methods of the non-radiative Auger recombination weakening is to use structures with strain layers. In our case the quantum-well layer consists of three $\operatorname{In}_{(1-x)} \mathrm{Ga}_{x} \mathrm{As}_{y} \mathrm{Sb}_{(1-y)}$ quantum wells with the lat- 
tice constant $a_{x}=0.6165 \mathrm{~nm}$ and with $a_{0}=0.6096 \mathrm{~nm}$ for the barrier layer $\mathrm{Al}_{(1-x)} \mathrm{Ga}_{x} \mathrm{As}_{y} \mathrm{Sb}_{(1-y)}$. As $a_{x}>a_{0}$ we have compressive strain case [4]. The data for mathematical model are in Table 1.

\begin{tabular}{|c|c|}
\hline Parameters & Numerical values \\
\hline Active layer mole fraction & $x=0.65 y=0.15$ \\
\hline Barrier layer mole fraction & $x=0.65 y=0.03$ \\
\hline Number of quantum wells & 3 \\
\hline Quantum well thickness & $10 \mathrm{~nm}$ \\
\hline Barrier layer thickness & $30 \mathrm{~nm}$ \\
\hline Cavity length & $820 \mu \mathrm{m}$ \\
\hline Internal quantum efficiency & 75 \\
\hline
\end{tabular}

Table 1. The data for mathematical model.

To investigate the non-radiative recombination we made the calculation in accordance with [3] where the following Auger recombination processes are taken into account: interaction of three electrons and a heavy hole $(\mathrm{CCCH})$; an electron, two heavy holes and a light hole (CHHL); an electron, two heavy holes and a hole of spinorbit splitting band (CHHS).

Thus, in each process three particles participate Auger recombination coefficient is inversely proportional to $n^{3}$, where $n$ is the carrier density. In this case the Auger recombination coefficient can be defined as follows:

$$
C=R_{a} / n^{3}
$$

where $R_{a}$ is the Auger recombination rate. The influence of Auger recombination processes on the quantum well semiconductor lasers performance depends on the distance between corresponding band energy quantizing levels which take part in the Auger transitions or for electron - split-off hole process on the difference between this value and the split-off band energy.

In common (bulk) case the dependence of the Auger recombination coefficient versus the temperature is expressed by formula [5]:

$$
C=C_{0} \exp \left(-\frac{E a}{k_{\mathrm{B}} T}\right)
$$

where $C_{0}$ is the Auger recombination coefficient which does not depend on the temperature; $E_{a}$ is the Auger process activation energy; $k_{\mathrm{B}}$ is the Boltzmann constant; $T$ is the temperature.

For every three processes which we consider the activation energy equals to:

- for CCCH process:

$$
E_{a}(\mathrm{CCCH})=\Delta m_{\mathrm{CCCH}} E_{\mathrm{C} 1 \mathrm{H} 1}(T)
$$

$$
\Delta m_{\mathrm{CCCH}}=\frac{m_{c}}{m_{c}+m_{h h}}
$$

— for CHHS process:

$$
\begin{aligned}
& E_{a}(\mathrm{CHHS})=\Delta m_{\mathrm{CHHS}}\left(E_{\mathrm{C} 1 \mathrm{H} 1}(T)-\Delta_{s},\right) \\
& \Delta m_{\mathrm{CHHS}}=\frac{m_{s}}{2 m_{h h}+m_{c}-m_{s}},
\end{aligned}
$$

— for CHHL process:

$$
\begin{aligned}
& E_{a}(\mathrm{CHHL})=\Delta m_{\mathrm{CHHL}} E_{\mathrm{C} 1 \mathrm{~L} 1}(T), \\
& \Delta m_{\mathrm{CHHL}}=\frac{m_{c}}{2 m_{h h}+m_{c}-m_{l h}}
\end{aligned}
$$

where $E_{\mathrm{C} 1 \mathrm{H} 1}$ is the distance between the first quantizing levels in the conduction band and the heavy hole subband; $m_{c}$ is the electron effective mass; $m_{h h}$ is the heavy hole effective mass; $\Delta_{s}$ is the split-off band energy; $m_{s}$ is the split-off hole effective mass; $E_{\mathrm{C} 1 \mathrm{~L} 1}$ is the distance between first quantizing levels in the conduction band and the light hole subband; $m_{l h}$ is the light hole effective mass. The total Auger recombination coefficient is defined by the processes sum:

$$
C_{\text {total }}=C_{\mathrm{CCCH}}+C_{\mathrm{CHHS}}+C_{\mathrm{CHHL}} \text {. }
$$

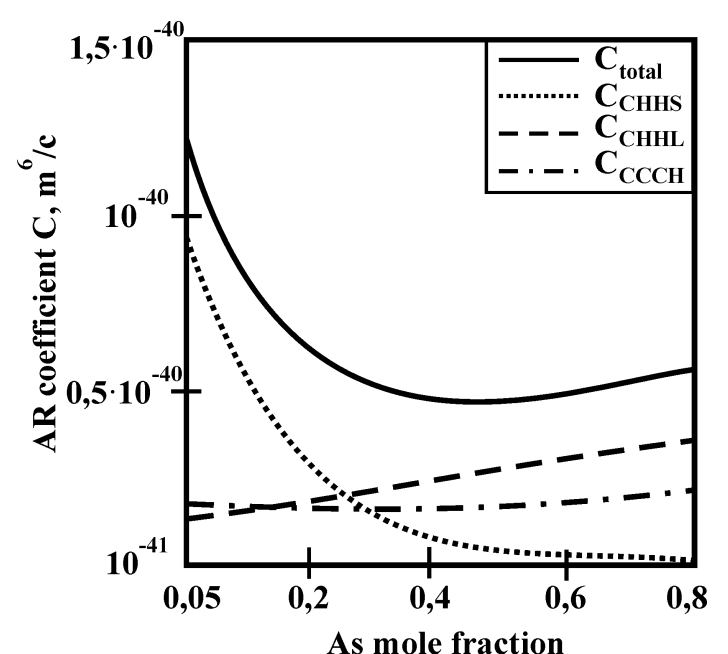

Fig. 1. Auger recombination coefficients versus temperature.

In Fig. 1 the total Auger recombination coefficient versus As mole fraction dependence is shown where one can see the presence of minimum on the total Auger recombination coefficient curve. To explain this occurance the behavior of each Auger recombination coefficients should be considered. The reason for such a behaviour is the activation energy change as the reduction of the energy between the first quantizing levels for all processes occurs; effective mass ratios in (5), (7) and (9) have small 
values at the same time. The CHHS process falling is concerned with the decreasing value of $\Delta_{s}$, i.e., an increase of the split-off band splitting and a decrease of the CHHS process take place.

Fig. 2 shows the calculated threshold current temperature dependence which illustrates perfect agreement with the experiment held by Y. Rouillard [6]. The reduction nonradiative current $\left(I_{C}\right)$ contribution to the total threshold current is observed at near and above room temperature while the role of radiative current $\left(I_{B}\right)$ is rising.

The obtained Auger recombination coefficient minimum which leads to the threshold current reduction points to the As optimal mole fraction availability in the structure which we investigate that allows to produce semiconductor mid-IR detectors ensuring steady generation at room temperature.

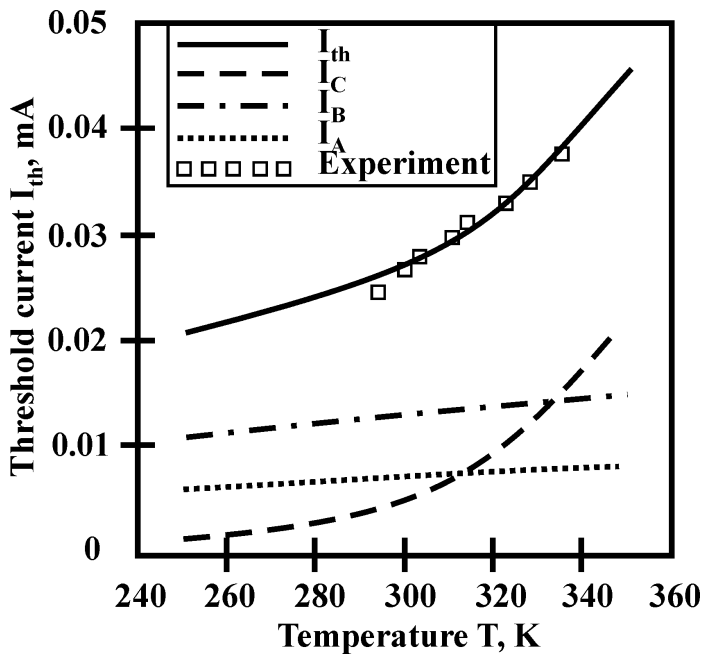

Fig. 2. Threshold current versus temperature.
[1] D. A. Yarekha et al., Semicond. Sci. Technol. 15, 1 (2000).

[2] G. P. Agrawal, N. K. Dutta, Long-wavelength semiconductor lasers (Van Nostrand Renhold Co., New York, 1993).

[3] A. Haug, J. Phys. Chem. Solids 49, 6 (1988).

[4] S. L. Chuang, Physics of optoelectronic devices (John Wi- ley, New York, 1995).

[5] A. F. Phillips, S. J. Sweeney, A. R. Adams, P. J. A. Thijs, J. Select. Topics Quantum Electron. 5, 3 (1999).

[6] Y. Rouillard, F. Genty, A. Perona et al., Philos. Trans. R. Soc. London A 359, 581 (2001).

\title{
ПОРОГОВА РЕДУКЩІЯ СТРУМУ У ШАРУВАТІЙ СТРУКТУРІ GaAsSb
}

\author{
О. Машошіна, В. Лисак, І. Сухойванов \\ Харківсъкий начіональний університет радіоелектроніки, \\ просп. Леніна, 14, Харків, 61166, Украӥна
}

\begin{abstract}
Проведено теоретичне дослідження температурної залежности порогового струму у квантоворозмірних структурах середнього IЧ-діяпазону з напруженими шарами на основі InGaAsSb/GaS та InGaAsSb/AlGaAsSb. Серед багатьох процесів, що впливають на температурну залежність порогового струму, вибрано та розглянуто Оже-рекомбінащію, яка має найбільший вплив на температурну характеристику. Отримана залежність коефіцієнтів Оже-рекомбінащії від молярних фракцій структури, що розглядається, ілюструє наявність мінімуму на џій залежності, а також шлях до зниження цього механізму втрат — це підбір матеріялу структури та його молярних фракцій. Одержані результати дають змогу зменшити безвипромінювальні втрати та температурну залежність порогового струму.
\end{abstract}

